\title{
Refund Beneficiaries and Refund Credits Under the Natural Gas Act
}

The purpose of federal regulation of the interstate natural gas market is to "afford consumers a complete, permanent, and effective bond of protection from excessive rates and charges." 1 When a natural gas company subject to the jurisdiction ${ }^{2}$ of the Federal Power Commission (FPG) proposes a change in its rates or charges, ${ }^{3}$ the Commission may initiate a hearing pursuant to section $4(e)$ of the Natural Gas Act," to determine whether the proposed rates are "just and reasonable."' The Commission may order an interim postponement of the proposed changes for a maximum of five months. ${ }^{6}$ If the Commission hearing is not concluded by the end of this period, the natural gas company may begin charging the proposed rates, but the Commission may require the company to post a bond to guarantee the refund of any portion of the new rate eventually found to be unjust or unreasonable. ${ }^{7}$

1 Atlantic Ref. Co. v. Public Serv. Comm'n, 360 U.S. 378, 388 (1959); accord, FPC v. Tennessee Gas Transmission Co., 371 U.S. 145, 154 (1962); FPC v. Hope Natural Gas Co., 320 U.S. 591, 610 (1944).

The original \& 7(c) of the Natural Gas Act provided:

[It is] the intention of Congress that natural gas shall be sold in interstate commerce

for resale for ultimate public consumption for domestic, commercial, industrial, or

any other use at the lowest possible reasonable rate consistent with the maintenance of adequate service in the public interest.

Natural Gas Act § 7(c), ch. 556, § 7(c), 52 Stat. 825 (1938), as amended, 15 U.S.C. § 717f(c) (1970).

2 The transportation and sale of natural gas in interstate commerce is regulated by the Federal Power Commission under the Natural Gas Act. 15 U.S.G. \$§ 717-717w (1970). For a discussion of the jurisdiction of the Federal Power Commission over rates in the natural gas market see text and notes at notes 15 to 21 infra.

3 The Act requires natural gas companies to provide the Commission with thirty days' notice of proposed changes in rates, but the Commission may allow changes in rates to become effective without thirty days' notice if there is good cause to relax the requirement. Natural Gas Act § 4(d), 15 U.S.C. § 717c(d) (1970).

415 U.S.C. $\$ 717 c(\mathrm{e})(1970)$.

$5 \quad I d$. Section $4($ a) of the Act declares that any rate which is not just and reasonable is unlawful. 15 U.S.C. $\$ 717 c(a)$ (1970).

6 Natural Gas Act $\S 4(e)$, 15 U.S.C. \$ 717c(e) (1970). A full discussion of the summary power of federal administrative agencies to suspend proposed rates can be found in Spritzer, Uses of the Summary Power to Suspend Rates: An Examination of Federal Regulatory Agency Practices, 120 U. PA. L. Rev. 39 (1971). Spritzer examines the practices of the Interstate Commerce Commission, the Federal Communications Commission, the Civil Aeronautics Board, and the Federal Power Commission.

7 The bond provisions of section $4(\mathrm{e})$ obviously apply only to proposed increases in rates. 15 U.S.G. § 717c(e) (1970). 
The Commission has recently altered its interpretation of how and to whom section 4(e) refunds are to be made. The Act does not specify the recipient of the refund, but from 1938 until 1968, the FPC required payment of refunds to the immediate pipeline purchaser who paid the increased rates while the section 4 (e) proceeding was pending. ${ }^{8}$ Under the Commission's new "flow through" refund policy," that purchaser may be passed over and the Commission may require payment of refunds to subsequent purchasers in the chain of distribution. This "flow through" approach lowers the immediate pipeline purchaser's return for the period during which the supplier's proposed rates were charged, ${ }^{10}$ and potentially increases refunds to ultimate

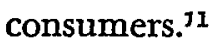

A recent Commission interpretation of section $4(e)$ also permits the forgiveness of refund obligations of a natural gas producer $^{12}$ through refund credits $^{13}$ granted if the producer dedicates new gas reserves to sales in interstate pipeline. ${ }^{14}$ The refund credit option provides the overcharged consumer with a monetary refund only if the natural gas producer elects to make cash payments or fails to have its entire refund obligation forgiven under the terms of the refund credit order. The

8 See, e.g., Gulf Oil Corp., 29 F.P.C. 837, 841 (1963); Ameranda Petroleum Corp., 29 F.P.C. 203, 207 (1963).

9 Texas Eastern Transmission Corp., 39 F.P.C. 630 (1968), aff'd, Texas Eastern Transmission Corp. v. FPC, 414 F.2d 344 (5th Cir. 1969), cert. denied, 398 U.S. 928 (1970). See also Texas Eastern Transmission Corp. v. FPC, 470 F.2d 757 (5th Cir. 1972); Texas Eastern Transmission Corp. v. FPC, 357 F.2d 232 (5th Cir. 1966).

10 The new flow through refund policy does not retroactively lower the immediate pipeline purchaser's return on investment in every case. See pp. 800-01 infra for a complete discussion of the factors which determine whether the flow through refund policy will have this effect.

11 The flow through refund policy does not guarantee the payment of increased refunds to the ultimate consumer because only state regulatory bodies have the authority to order local distributors to refund payments to ultimate consumers. See text and notes at notes 15-21 infra.

12 Sales of natural gas by producers in interstate commerce for resale are covered by the Natural Gas Act. Phillips Petroleum Co. v. Wisconsin, 347 U.S. 672 (1954); Natural Gas Act § 2(6), 15 U.S.C. § 717a(6) (1970).

13 Area Rate Proceeding (Southern Louisiana Area II), 46 F.P.C. 86 (1971), affd sub nom. Placid Oil Co. v. FPG, 483 F.2d 880 (5th Gir. 1973), affd sub nom. Mobil Oil Corp. v. FPC, 94 S. Ct. 2328 (1974); Area Rate Proceeding (Texas Gulf Coast Area) 45 F.P.C. 674 (1971), remanded sub nom. Public Serv. Comm'n v. FPC, 487 F.2d 1043 (D.C. Cir. 1973), cert. granted and judgment vacated sub nom. Shell Oil Co. v. Public Serv. Comm'n, $94 \mathrm{~S}$. C. 3166 (1974) (judgment vacated and cases remanded for further consideration in light of Mobil Oil Corp. v. FPC, supra); Area Rate Proceeding (Other Southwest Area), 46 F.P.C. 900 (1971), aff'd sub nom. Shell Oil Co. v. FPC, 484 F.2d 469 (5th Cir. 1973), petition for cert. filed, 42 U.S.L.W. 3231 (U.S. Sept. 6, 1973) (No. 73-438).

14 For a full discussion of the refund credit program and a definition of new gas see text and notes at notes 83-86 infra. 
option also has economic effects on the allocation of resources to the discovery of new gas and the distribution of wealth among consumers.

This comment examines the structure of federal regulation of the natural gas industry and analyzes the development of the refund flow through policy and the refund credit option in light of statutory limitations on the Commission's power. The comment concludes that neither the flow through refund policy nor the refund credit program is authorized by the Natural Gas Act.

\section{Regulation of the Natural Gas Market}

\section{A. Structure of the Natural Gas Market and the Regulatory Mechanism ${ }^{15}$}

Producers of natural gas enter into long term contracts ${ }^{16}$ for the sale of natural gas in two markets: the home state market and the interstate market. ${ }^{17}$ The Federal Power Commission has jurisdiction only over the rates charged in sales of natural gas in interstate commerce for resale, ${ }^{18}$ often referred to as jurisdictional sales. The FPC therefore

15 This section draws heavily on a similar discussion in Gerwig, Natural Gas Production: A Study of Costs of Regulation, 5 J. LAw \& Econ. 69, 70-73 (1962). See generally E. Falck \& F. Weich, Federal Regulation of Naturad Gas in the Untted Statrs (1958); J. Hodges, Naturai Gas: Price Regulation vs. Supply (1970); E. Neuner, The Natural Gas INDUSTRY (1960).

16 Natural gas is transported by pipeline from producer reserves to the eventual user. A contract for the purchase of natural gas is enforceable for the life of the reserves. Gerwig, supra note 15 , at 70 .

17 Purchasers in the home state market may be either (1) industrial customers who purchase gas for their own use, (2) intrastate or interstate pipeline companies who purchase gas for resale in intrastate commerce to industrial customers, or (3) intrastate pipeline companies who purchase gas for resale in intrastate commerce to local distributors. Purchasers in the interstate market are interstate pipeline companies who resell gas in interstate commerce to industrial customers for their own use or to intrastate local distributors for resale to residential and commercial users and industrial customers. The chain of distribution in the interstate market between producers and local distribution companies may involve several interstate pipeline companies who resell to each other before the gas reaches the intrastate distributor. Gerwig, supra note 15, at 71.

18 Section 1(b) of the Natural Gas Act provides:

The provisions of this chapter apply to the transportation of natural gas in interstate commerce, to the sale in interstate commerce of natural gas for resale for ultimate public consumption for domestic, commercial, industrial, or any other use, and to natural-gas companies engaged in such transportation or sale, but shall not apply to any other transportation or sale of natural gas or to the local distribution of natural gas or to the facilities used for such distribution or to the production or gathering of natural gas.

15 U.S.C. § 717(b) (1970).

The Commission does not have jurisdiction over the rates charged in intrastate sales (sales in the home state market) or interstate sales which are not for resale (sales to industrial customers for their own use). Although the Commission does not have jurisdiction over rates in interstate direct sales (sales not for resale), the Supreme Court has interpreted section 1 of the Natural Gas Act to give the FPG jurisdiction over aspects of the "trans- 
regulates the rates charged by interstate pipeline companies to each other and to local distributors, and state regulatory authorities regulate the rates charged by local distributors to industrial, residential, and commercial users. ${ }^{10}$

In regulating these rates, state authorities must consider the rates paid by the local distributors to interstate pipeline companies-rates over which state regulatory authorities have no control. ${ }^{20}$ Thus, federal regulation seeks to assure reasonable rates for the ultimate consumer by limiting the rates charged by interstate pipeline companies to a "just and reasonable" level. ${ }^{21}$

\section{B. Federal Regulation of Rates in Sales of Natural Gas in Interstate Commerce for Resale}

Federal control over rates in jurisdictional sales can be exercised when a natural gas company first seeks permission to operate in interstate commerce, ${ }^{22}$ when a complaint is made as to the reasonableness of existing rates, ${ }^{23}$ or when a natural gas company proposes new rates. ${ }^{24}$ This comment will deal with only the latter two situations.

Upon complaint by a third party or at any time upon its own motion, the Commission may undertake a hearing under section 5 (a) of the Act $^{25}$ to determine the reasonableness of rates charged in jurisdictional

portation" of natural gas in direct sales, such as curtailment plans for periods of shortage. FPC v. Louisiana Power \& Light Co., 406 U.S. 621 (1972).

19 If there is no state or municipal regulation of intrastate sales, the rates are governed by contract. See, e.g., New Mexico Elec. Serv. Co. v. Public Serv. Comm'n, 81 N.M. 683, 472 P.2d 648 (1970).

20 Missouri v. Kansas Natural Gas Co., 265 U.S. 298 (1924).

21 See generally Hearings on H.R. 11662 Before a Subcomm. of the House Comm. on Interstate and Foreign Commerce, 74th Cong., 2d Sess. (1936).

22 Section 7(e) of the Natural Gas Act, as amended, provides in part:

The Commission shall have the power to attach to the issuance of the certificate and

to the exercise of the rights granted thereunder such reasonable terms and conditions

as the public convenience and necessity may require.

15 U.S.C. $\S 717 f(e)(1970)$.

A natural gas company cannot engage in the sale or transportation of natural gas subject to the jurisdiction of the FPC without a certificate of public convenience and necessity. Section 7 of the Act, which gives the Commission authority to issue both temporary and permanent certificates, has been interpreted by the courts to give the Commission authority to attach both maximum price limitations and refund provisions to the issuance of these certificates. Atlantic Ref. Co. v. Public Serv. Comm'n, 360 U.S. 378 (1959); United Gas Improvement Co. v. Callery Properties, Inc., 382 U.S. 223 (1965).

23 Natural Gas Act \& 5(a), 15 U.S.C. \$ 717d(a) (1970).

24 Natural Gas Act \& 4(e), 15 U.S.C. \$ 717c(e) (1970).

25 Section 5(a) of the Natural Gas Act provides:

Whenever the Commission, after a hearing had upon its own motion or upon com. plaint of any State, municipality, State commission, or gas distributing company, shall find that any rate, charge, or classification demanded, observed, charged, or collected by any natural-gas company in connection with any transportation or sale of natural gas, subject to the jurisdiction of the Commission, or that any rule, regulation, prac- 
sales. ${ }^{26}$ If the Commission concludes that the rates are "unjust or unreasonable," it may establish a new rate, ${ }^{27}$ subject to two limitations: first, the remedy for unreasonable rates is prospective only-no damages may be assessed to remedy past unreasonable rates; ${ }^{28}$ and second, the Commission bears the burden of proving that current rates are unjust or unreasonable. ${ }^{29}$

\section{Under section $4(e)$ of the Act, ${ }^{30}$ the Commission can exercise control}

tice, or contract affecting such rate, charge, or classification is unjust, unreasonable, unduly discriminatory, or preferential, the Commission shall determine the just and reasonable rate, charge, classification, rule, regulation, practice, or contract to be thereafter observed and in force, and shall fix the same by order: Provided, however, That the Commission shall have no power to order any increase in any rate contained in the currently effective schedule of such natural gas company on file with the Commission, unless such increase is in accordance with a new schedule filed by such natural gas company; but the Commission may order a decrease where existing rates are unjust, unduly discriminatory, preferential, otherwise unlawful, or are not the lowest reasonable rates.

15 U.S.C. $\$ 717 \mathrm{~d}(\mathrm{a})(1970)$.

26 The Supreme Court interpreted the scope and nature of section 5(a) review of rates in United Gas Pipe Line Co. v. Mobile Gas Serv. Corp., 350 U.S. 332 (1956):

The basic power of the Commission is that given to it by $\S 5$ (a) to set aside and modify any rate or contract which it determines, after hearing, to be "unjust, unreasonable, unduly discriminatory, or preferential." This is neither a "rate-making" nor a "rate-changing" procedure. It is simply the power to review rates and contracts made in the first instance by natural gas companies and, if they are determined to be unlawful, to remedy them.

Id. at 341 .

27 The Commission cannot establish a new rate that is higher than the old rate uniess the natural gas company agrees. Natural Gas Act § 5(a), 15 U.S.C. § 717d(a) (1970). The full text of section 5(a) appears in note 25 supra.

28 If the Commission investigates a rate of $\$ 2$ per unit, for example, and finds that rate to be just and reasonable, no purchaser can be awarded reparations or damages if the Commission later reconsiders the $\$ 2$ rate and finds it to be unreasonable. The FPC's sole remedy would be a reduction of the rate from the date of its reconsideration. The Commission has no reparation power. FPG v. Hope Natural Gas Co., 320 U.S. 591, 618 (1944); Montana Dakota Utils. Co. v. Northwestern Public Serv. Co., 341 U.S. 246, 251 (1951).

There is a qualification on the ban on reparations-it applies only to rates that have become unconditionally effective. For example, if the issuance of a permanent certificate is subject to judicial review and the case is remanded to the FPC, the Commission has the authority to attach refund conditions to the new permanent certificates requiring refund of amounts collected under the erroneously issued certificates in excess of the finally determined price. United Gas Improvement Co. v. Callery Properties, 382 U.S. 223 (1965).

29 Continental Oil Co., 17 F.P.C. 880, 885 (1957) (Commissioner Connole dissenting); Spritzer, supra note 6 , at 39 \& n.l.

30 Section $4(e)$ provides:

Whenever any such new schedule is filed the Commission shall have authority, either upon complaint of any State, municipality, State commission, or gas distributing company, or upon its own initiative without complaint, at once, and if it so orders, without answer or formal pleading by the natural-gas company, but upon reasonable notice, to enter upon a hearing concerning the lawfulness of such rate, charge, classification, or service; and, pending such hearing and the decision thereon, the commission, upon filing with such schedules and delivering to the natural-gas company affected thereby a statement in writing of its reasons for such suspension, may suspend the operation of such schedule and defer the use of such rate, charge, classification, or service, but not for a longer period than five months beyond the time when it would otherwise go into effect; and after full hearings, either completed before or after the 
over rates in jurisdictional sales when a natural gas company files proposed rates with the Commission. ${ }^{31}$ Although the Commission could proceed to investigate proposed rates by allowing them to take effect and then instituting a section 5(a) hearing upon its own motion, section 4(e) provides the Commission with three advantages not available under section 5(a). First, the FPG can preserve the existing rate structure by suspending the operation of the proposed rates for five months. Second, even if the Commission hearing lasts longer than five months and the natural gas company puts the proposed rates into effect, the Commission can make its rate decision retroactive by means of the refund procedure. Third, in a section $4(e)$ hearing the natural gas company has the burden of proving that the proposed rates are just and reasonable. ${ }^{32}$

Although the Commission's order at the conclusion of its section 4(e) proceedings may apply retroactively by requiring the refund of excessive amounts collected after the effective date of the proposed rate, the Commission is precluded, as under section 5(a), from ordering a retroactive remedy-damages or reparations-that would in effect lower the rate for the refund period below the original rate. ${ }^{33}$ Thus, even if it

rate, charge, classification, or service goes into effect, the Commission may make such orders with reference thereto as would be proper in a proceeding initiated after it had become effective. If the proceeding has not been concluded and an order made at the expiration of the suspension period, on motion of the natural-gas company making the filing, the proposed change of rate, charge, classification, or service shall go into effect. Where increased rates or charges are thus made effective, the Commission may, by order, require the natural-gas company to furnish a bond, to be approved by the Commission, to refund any amounts ordered by the Commission, to keep accurate accounts in detail of all amounts received by reason of such increase, specifying by whom and in whose behalf such amounts were paid, and, upon completion of the hearing and decision, to order such natural-gas company to refund, with interest, the portion of such increased rates or charges by its decision found not justified. At any hearing involving a rate or charge sought to be increased, the burden of proof to show that the increased rate or charge is just and reasonable shall be upon the natural-gas company, and the Commission shall give to the hearing and decision of such questions preference over other questions pending before it and decide the same as speedily as possible.

15 U.S.C. \& $717 c(e)(1970)$.

31 The Supreme Court has interpreted section 4(e) as a supplement to the FPC's power under section $5(a)$ :

All that $\& 4(e)$ does, however, is to add to this basic power, in the case of a newly changed rate or contract (except in "industrial" rates), the further powers (l) to preserve the status quo pending review of the new rate by suspending its operation for a limited period, and (2) thereafter to make its order retroactive by means of the refund procedure, to the date the change becomes effective.

United Gas Pipe Line Co. v. Mobile Gas Serv. Corp., 350 U.S. 332, 341 (1956).

3215 U.S.C. $\$ 717 c(e)(1970)$.

83 FPC v. Sunray DX Oil, 391 U.S. 9, 24-25 (1968). In Sunray, the Court reviewed a Commission section 4(e) refund order requiring refunds in excess of the difference between the original rates and the proposed new rates. The Court held that the FPC could not order these refunds simply because the eventually determined just and reasonable rate was below the original rate-the refund order amounted to an award of reparations. 
appears that the original rate charged by the natural gas company was unjust and unreasonable, the FPC may do no more than require a refund of the amounts collected under the proposed rate in excess of the original rate. ${ }^{34}$ The Commission may, of course, set a rate for future periods below even the original rate.

\section{Beneficiaries of the Refund ORder: To Whom Must Refunds Be Pam?}

\section{A. Development of the Flow Through Refund Policy .}

When a natural gas supplier increases its rates to an intermediate pipeline purchaser, the latter generally seeks to protect its return on investment by raising its rates-ctracking" the supplier's increase. ${ }^{35}$ If all pipeline purchasers in the chain of distribution respond in this manner, supplier rate increases reach intrastate distributors and, subject to action by state regulatory bodies, ${ }^{36}$ will reach the ultimate consumer. Similarly, the impact of any refunds ordered at the completion of the supplier's section 4(e) proceeding also reaches the consumer because the tracking rate increases will be disallowed to the same extent as the supplier increase. ${ }^{37}$ Because the intermediate pipeline purchaser is able to track his supplier's rates, he is able to maintain his return on investment, ${ }^{38}$ one that can be easily reviewed by the FPG when the tracking rate increase is filed. ${ }^{39}$

34 Id. at 24.

35 This tracking rate increase, like the initial supplier rate increase, becomes effective after five months subject to the section 4(e) refund provisions, but the Commission would presumably allow the increase to take effect without suspension. See Spritzer, supra note 6, at $89 \mathrm{n} .207$.

38 See text and notes at notes 15-21 supra.

37 This conclusion assumes that the pipeline purchaser's other costs remain unchanged.

38 If an intermediate pipeline purchaser is making a reasonable return of 6 percent (the figures in this and other examples are illustrative only) prior to a supplier rate increase, fling a tracking rate increase in response to a supplier rate increase will maintain this 6 percent return. Although the intermediate pipeline purchaser's receipt of refunds (upon disallowance of the supplier rate increase in whole or in part) would raise its return above 6 percent, its tracking rate increase would also be disallowed and it would thus make refunds to its own customers restoring its 6 percent return.

39 It is not at all clear why a pipeline purchaser would fail to file a tracking rate increase. A pipeline purchaser making a reasonable return would certainly file a tracking rate increase to prevent an unnecessary reduction of that return. The decision for a pipeline purchaser making an unreasonably high return, however, presents a more complicated situation. If the pipeline purchaser fails to file a tracking rate increase it runs the risk that the supplier rate increase will be allowed in full or in part resulting in a reduction of its unreasonably high return. But if the pipeline purchaser files a tracking rate increase, it runs the risk that the FPC will discover its unreasonably high return in the course of the section 4 (e) tracking rate hearing. The decision is in effect a gamble and would be a function of the pipeline purchaser's preference for risk. 
Before 1968, the FPC routinely ordered the payment of section 4(e) refunds to the pipeline purchaser who had paid the increased rates. ${ }^{40}$ Thus, a pipeline purchaser who decided not to file a tracking rate increase (effectively lowering its return on investment if no refund was forthcoming) received all supplier refunds. Because it had not passed the increase on to its customers, this pipeline purchaser was not required to make refunds to them. ${ }^{41}$ The Commission eventually suggested that failure to file a tracking rate increase could be evidence that the pipeline purchaser had been making an unreasonably high return on investment, ${ }^{42}$ to the ultimate detriment of the consumer. If the Commission used the failure to file a tracking rate increase as a trigger for a section 5(a) proceeding and decided on the same day to reduce prospectively the pipeline purchaser's rate of return, it would have achieved all that section 5 (a) permits.

The Commission does not make rate decisions that quickly, however, and if the section 5(a) procedure is used, consumers would continue to be overcharged during its pendency. To eliminate this problem, ${ }^{43}$ the Commission in 1968 relied on its section 4(e) power to establish a new flow through refund policy in the Texas Eastern Transmission Corp. ${ }^{44}$ case. Under the new policy, a pipeline purchaser who pays increased costs under a supplier rate increase is entitled to supplier refunds only if it (I) files a tracking rate increase, and (2) proves that it made only a reasonable return on investment for the period during which the

40 See, e.g., Gulf Oil Corp., 29 F.P.C. 837, 841 (1963); Ameranda Petroleum Corp., 29 F.P.C. 203, 207 (1963).

41 If a pipeline purchaser was making an unreasonably high return on investment of 8 percent prior to a supplier rate increase that lowered its return to 6 percent, receipt of supplier refunds under the pre-1968 procedure would restore its return to 8 percent retroactive to the date the proposed supplier rate increase took effect (if the supplier rate increase was disallowed in full). If the supplier rate increase was disallowed in part, the pipeline purchaser's return would be retroactively restored to a rate between 6 and 8 percent.

42 The Commission suggested that an immediate pipeline purchaser making only a reasonable return would normally file a tracking rate increase to preserve that return, but a pipeline purchaser left, after the supplier rate increase, with either a lower but still unreasonably high return or a reasonable return would fail to file to avoid an investigation of its own rates. See Texas Eastern Transmission Corp., 39 F.P.C. 630, 639-40 (1969).

43 In its 1963 Annual Report, the Commission presents the results of a natural gas rate refund survey and notes that local distributing utilities passed on to ultimate consumers only 58 percent of the monies they received as refunds in the survey period. 43 FPC ANN. REP. 127 (1963). This expression of concern is interesting because the Commission expressed an intent in the same year not to determine the refund obligations of local distributors, which are subject to state rather than federal regulation. See Hunt Oil Corp., 30 F.P.C. 220 (1963).

4439 F.P.C. 630 (1968), aff'd, Texas Eastern Transmission Corp. v. FPC, 414 F.2d 344 (5th Cir. 1969), cert. denied 398 U.S. 928 (1970). 
supplier rate increase was in effect. ${ }^{45}$ If the pipeline purchaser fails to track the supplier rate increase, the Commission will order the distribution of refunds by the supplier to the first local distributor in the chain of distribution, bypassing completely the pipeline purchaser who was actually charged the higher rates. ${ }^{46}$ If the pipeline purchaser tracks the supplier rate increase but fails to prove it had made only a reasonable return on investment, the Commission will also order distribution of refunds by the pipeline purchaser to its own customers.

The rationale behind this policy is clear. First, if a pipeline purchaser is able to continue operations without a tracking increase, it was making an unreasonably high rate of return up to the time of the supplier rate increase. The payment of any refund to that pipeline purchaser would simply restore its unreasonable return for the period during which the supplier's rate increase was effective. If, however, the refund passes from the supplier to someone in the chain of distribution below the pipeline purchaser, the pipeline purchaser is effectively forced to take a reduced rate of return for the period during which the supplier's rate was effective. Second, if a pipeline purchaser files a tracking rate increase and the hearing discloses an unreasonable rate of return, the routing of any supplier refunds around the pipeline purchaser provides a convenient means of retroactively reducing the pipeline purchaser's rate of return.

The flow through refund scheme thus allows the Commission to force retroactive rate reductions, a technique not available in section 5 (a) procedings. It must be noted, however, that the flow through refund scheme provides only limited power to order retroactive rate reductions. The system works only if there is a supplier rate increase that is subsequently disallowed in whole or in part, and the extent of the

45 The latter determination takes into account the pipeline purchaser's increased costs due to the supplier rate increase and its increased revenues under its tracking rate increase.

46 If a pipeline purchaser was making an unreasonable return on investment of 8 percent and a supplier rate increase reduced this return to 6 percent, a tracking rate increase would xestore the 8 percent return. If the supplier rate increase is disallowed in full, the FPC, acting under the flow through refund procedure, can order the payment of two refunds to the local distributor: the Commission can require the supplier to pay refunds under its initial rate increase and the pipeline purchaser to pay refunds under its tracking rate increase. (For each additional pipeline in the chain of distribution between the supplier and the local distributor there is another possible refund payment). This approach reduces the pipeline purchaser's return to 6 percent retroactive to the date of the tracking rate increase because the pipeline purchaser makes refunds under its tracking rate increase but receives no refunds from its supplier whose initial rate increase was disallowed in full. The new procedure therefore effectively prevents the pipeline purchaser who fails to meet the Texas Eastern requirements from capturing the alleged "windfall gain" in the form of supplier refunds. 
retroactive reduction is limited by the amount of the supplier rate increase.

\section{B. Is the New Refund Procedure Within the Commission's Statutory Power?}

It must be recognized at the outset that the critical component of the new refund policy is the practice of ordering a flow through of refunds to local distributors rather than to the pipeline purchaser. The tracking rate increase requirement, by itself, does not result in the elimination of the windfall gain to the latter. A pipeline purchaser making an unreasonably high return prior to a supplier rate increase would actually maintain that return if the Commission's new policy required only a tracking rate increase. For example, if a pipeline purchaser makes an unreasonable return of 10 percent, and a supplier rate increase lowers his return to 8 percent, the filing of a tracking rate increase will restore the 10 percent return. If the supplier rate increase is then disallowed in whole or in part, the pipeline purchaser receives a refund that is passed on to its customers when its tracking rate increase is similarly disallowed. The pipeline purchaser's net position remains unchanged with a return of 10 percent for the period covered by the supplier's refund obligation. The Commission can establish lower rates for the pipeline purchaser, but these new rates have only prospective effect. Thus, by itself, the tracking rate increase requirement fails to provide the Commission with control over a pipeline purchaser's return for the refund period. As discussed above, this control results only from diversion of the refund to someone other than the pipeline purchaser.

An analysis of whether the new refund procedure is within the Commission's statutory power must therefore focus on the FPC's practice of ordering a flow through of supplier refunds to local distributors rather than its authority to require pipeline purchasers to file tracking rate increases. Examination of the Commission's statutory power to effectuate the new refund procedure will center on the legislative history of the Act, judicial interpretation of the scope of review in section 4(e) proceedings, statutory limitations on the Commission's power, and the Commission's asserted justification for the new procedure.

1. Legislative History. ${ }^{47}$ Although the Natural Gas Act, like several other regulatory statutes, ${ }^{48}$ contains an accounting provision under

47 See generally Note, Legislative History of the Natural Gas Act, 44 GEO. L.J. 695 (1956).

18 Federal Power Act, § 205(e), 16 U.S.C. \$ 824d(e) (1970) (Federal Power Commission 
which the amount of increased rates collected from each purchaser is recorded, only the Natural Gas Act fails to require that refunds be paid to the "persons in whose behalf such amounts were paid." The first House bill ${ }^{49}$ to regulate the gas market, introduced in 1935, included the requirement, but after extensive hearings ${ }^{50}$ the section of the bill covering the regulation of the natural gas market ${ }^{51}$ was not reported to Congress. In 1936, a bill containing the requirement was reported out, ${ }^{52}$ but the bill itself failed to pass. The 1937 bill $^{53}$ that was to become the Natural Gas Act inexplicably did not include the requirement; there was no discussion of the refund beneficiary problem in either the hearings ${ }^{54}$ on the bill as proposed, or the Congressional debates $^{55}$ on the bill as reported. ${ }^{56}$

The legislative history thus fails to clarify the question of statutory power, ${ }^{57}$ and an analysis of that question must center largely on judicial interpretation of the scope of the Commission's review in section 4(e) proceedings.

2. Judicial Interpretation of the Scope of Review in Section 4(e)

regulation of electric utilities); Communications Act of 1934, § 204, 47 U.S.C. § 204 (1970);

Interstate Commerce Act, $\$ 15,49$ U.S.C. $\S 15(7)$ (1970). The Interstate Commerce Act was the model act for subsequent regulatory statutes. The statutes differ in ways which are not important here, such as the length of the suspension pexiod and whether or not a bond is required. See generally Spritzer, supra note 6.

49 H.R. 5423, 74th Cong., Ist Sess. (1935).

ธo Hearings on H.R. 5423 Before the House Comm. on Interstate and Foreign Commerce, 74th Cong., Ist Sess. (1935) (Public Utîlity Holding Companies).

61 Title III, H.R. 5423, 74th Cong., Ist Sess. (1935).

62 H.R. 12680, 74th Cong., 2d Sess. (1936). The bill was originally introduced as H.R. 11662, 74th Cong., 2d Sess. (1936) [hereinafter cited as the "1936 bill"] and was reported out after extensive hearings. Hearings on H.R. 11662 Before a Subcomm. of the House Gomm. on Interstate and Foreign Commerce, 74th Cong., 2d Sess. (1936) (Natural Gas).

53 H.R. 4008, 75th Cong., 1st Sess. (1937) [hereinafter cited as the "1937 bill"].

54 Hearings on H.R. 4008 Before the House Comm. on Interstate and Foreign Commerce, 75th Cong., 1st Sess. (1937) (Natural Gas).

5581 Cong. Rec. 6720-33, 8918, 9312-17 (1937); 83 CoNg. Rec. $8343-47$ (1938).

56 H.R. 6586, 75th Cong., 1st Sess. (1937).

57 Although this evidence could support a presumption that the deletion of the refund beneficiary provision was intentional, there is some evidence that Congress did not recognize any substantive procedural change in the deletion of the phrase "to the persons in whose behalf the amounts were paid." The House Reports accompanying the 1936 and 1937 bills contain identical explanations of the refund provision, and no mention is made of the refund beneficiary problem. H.R. REP. No. 2651, 74th Cong., 2d Sess. (1936); H.R. REP. No. 709, 75th Cong., 1st Sess. (1937). Furthermore, the Chairman of the House Committee on Interstate and Foreign Commerce noted in the 1937 hearings that the only substantially new feature of the 1937 bill was a provision requiring certificates of public convenience and necessity. Hearings on H.R. 4008 Before the House Comm. on Interstate and Foreign Commerce, 75th Cong., Ist Sess., at 23 (1937). 
Proceedings. In United Gas Pipe Line Co. v. Mobile Gas Service Corp. ${ }^{88}$ the Supreme Court limited the scope of section 4(e) review to determinations of the reasonableness of the rates set by the natural gas supplier. ${ }^{59}$ Thus, in the supplier's section 4(e) proceeding, the Commission may not consider whether the purchaser will make an unreasonable return on investment as a result of the disallowance of the supplier rate increase.

The narrow scope of review in a section 4(e) proceeding is consistent with the nature of federal regulation of the natural gas market. The Commission has authority to review rates at each stage in the interstate chain of distribution, and to adjust those rates if they are unlawful. Once the Commission approves a supplier's rates for jurisdictional sales, these rates become an immediate purchaser's "costs," which the Commission takes into account in determining whether the purchaser's rate provides him with a reasonable return. The Natural Gas Act does not authorize the Commission to exert direct control over a pipeline purchaser's costs. The expanded scope of review in the flow through refund procedure, however, in effect authorizes the FPC to establish a pipeline purchaser's prior "costs" at a level above its supplier's pre-increase rates by denying the pipeline purchaser an opportunity to recoup the increased costs that are eventually disallowed.

3. Statutory Limitations on the Commission's Power-the Ban on Reparations. A reparation award is a damage award for the collection of rates (including those that received Commission approval) in excess of a just and reasonable rate. The Commission cannot make reparation awards in either section $4(\mathrm{e})^{60}$ or section $5(\mathrm{a})^{61}$ proceedings since the statutory remedy for unreasonable rates is limited to prospective relief. ${ }^{62}$ Thus, if the Commission, acting under section $5(\mathrm{a})$, investigates a rate that it approved a year before and concludes it was unreasonably high, the only available remedy is to establish lower rates for future periods. The natural gas company collecting the unreasonably high rate is entitled to retain all sums collected prior to the conclusion of the Commission's second investigation.

The federal courts of appeals have generally concluded that the new

58350 U.S. 332 (1956). See note 31 supra.

59350 U.S. at 343 .

60 See text and notes at notes 33-34 supra.

61 See text and note at note 28 supra.

62 FPC v. Sunray DX Oil, 391 U.S. 9, 24 (1968); Montana-Dakota Utils. Co. v. Northwestern Pub. Serv. Co., 341 U.S. 246, 254 (1951); FPC v. Hope Natural Gas Co., 320 U.S. 591,618 (1944). 
flow through refund procedure does not involve an award of reparations. ${ }^{63}$ It is submitted, however, that the flow through refund policy violates the ban on reparations through the new control it gives the Commission over an intermediate pipeline purchaser's rates. Assume, for example, that a pipeline purchaser is making an unreasonably high return of 12 percent and that a supplier rate increase lowers this return to 10 percent. A tracking rate increase under the flow through refund procedure restores the pipeline purchaser's 12 percent return on investment. Disallowance of the supplier rate increase in full would result in a similar disallowance of the tracking rate increase, ${ }^{64}$ and the pipeline purchaser would be obligated to make refunds to its customers, thus reducing its return to 10 percent retroactive to the date of the tracking rate increase. Although receipt of supplier refunds by the pipeline purchaser would restore the 12 percent return, under the new flow through procedure the FPG can order payment of these refunds to ultimate consumers $^{65}$ to keep the pipeline purchaser's return at the more reasonable level of 10 percent, retroactive to the date the supplier increase went into effect. In this manner, the new flow through procedure enables the Commission to use a disallowed supplier rate increase to provide consumers with a reparations award for at least a portion of the unreasonable charges collected by the pipeline purchaser.

\section{The Commission's Asserted Justification for the Flow Through} Refund Procedure. The Commission ${ }^{66}$ and the courts ${ }^{67}$ have relied on what they deem an analogous situation in FPC $v$. Interstate Natural Gas $C o{ }^{68}$ to buttress their conclusion that the refund flow through procedure is within the Commission's statutory power. At the completion of a section 5(a) proceeding instituted by the Commission, Interstate

63 Public Serv. Comm'n v. FPC, Civil No. 24,716 (D.C. Cir., Mar. 25, 1974); Texas Eastern Transmission Corp. v. FPC, 414 F.2d 344 (5th Cir. 1969), cert. denied, 398 U.S. 928 (1970). See Texas Gas Transmission Corp. v. FPC, 441 F.2d 1392 (6th Cir. 1971) (accepting the Texas Eastern decision as settled law).

64 As noted earlier, this conclusion assumes that the pipeline purchaser's other costs remain unchanged. See text and note at note 37 supra.

65 Although the Commission has held that the ultimate consumers are the appropriate ultimate beneficiaries of the refunds, it has also held that the limits on its jurisdiction require distribution of refunds to local distribution companies rather than ultimate consumers. Texas Eastern Transmission Corp., 39 F.P.C. 630, 638 (1968). The Court of Appeals for the Fifth Circuit reached the same conclusion. Texas Eastern Transmission Corp. v. FPC, 414 F.2d 344, 350 (1969). See text and note at note 73 infra.

66 Texas Eastern Transmission Corp., 39 F.P.C. 630, 641 (1968).

67 See cases cited note 63 supra.

68336 U.S. 577 (1949). 
was ordered to lower its rates for future periods. ${ }^{60}$ The court, on appeal, stayed the rate reduction order pending review of the Commission's decision, but required Interstate to deposit in the registry of the court the monthly difference between customer payments under the existing rates and those that would be required under the Commission's rate reduction order. ${ }^{70}$ The court eventually decided that the rate reduction order was valid ${ }^{71}$ and ordered refund of the deposited monies to Interstate's immediate pipeline purchasers whose payments created the fund. ${ }^{22}$

The Supreme Court reversed and held that the court of appeals had the authority and responsibility to bypass the intermediate interstate pipeline companies and order a flow through of refunds to the ultimate consumer ${ }^{73}$ whenever it found they had suffered a loss as a result of the court's action in granting the stay. ${ }^{74}$ The consumers were injured in Interstate because they were prevented by the court's stay of the rate reduction order from invoking that order to obtain a reduction in the rates charged by local distributors from state regulatory bodies. ${ }^{75}$

69 Interstate Natural Gas Co., 3 F.P.C. 416 (1943), aff'd, Interstate Natural Gas Co. v. FPC, 156 F.2d 949 (1946), aff'd, 331 U.S. 682 (1947).

70 See Interstate Natural Gas Co. v. FPC, 166 F.2d 796, 797 n.I (5th Cir. 1948).

71 Interstate Natural Gas Co. v. FPG, 156 F.2d 949 (5th Gir. 1946), affd, 381 U.S. 682 (1947).

72 Interstate Natural Gas Co. v. FPC, 166 F.2d 796 (5th Cir. 1948), rev'd, 336 U.S. 577 (1949).

73336 U.S. 577 (1949). Justices Burton and Jackson were of the opinion that the court had no power to order payment of refunds beyond the local distribution companies. They based their argument on the fact that the Federal Power Commission had no authority under the Natural Gas Act to enter the local field for ratemaking, and a federal court could thus derive no additional power to enter the local field with refunds. Id. at 590-91. The opinion for the court by Justice Douglas appears to find authority for consumer refunds in the inherent power of a court of equity. $I d$. at 582-83.

74 Id. at 582-83 (1949). But cf. Central States Elec. Co. v. Muscatine, 324 U.S. 138 (1945). See also Pennsylvania Water and Power Co. v. FPG, 203 F.2d 219, 224-25 (1953); Cities Serv. Gas Co. v. FPG, 176 F.2d 548, 550-51 (1949).

Prior to 1945 , the Supreme Court had established the power of federal courts to protect parties injured by court injunctions by allowing recovery in the nature of restitution where that remedy was appropriate. United States v. Morgan, 307 U.S. 183 (1939); Inland Steel Co. v. United States, 306 U.S. I53 (1989); Ex parte Lincoln Gas \& Elec. Light Co., 256 U.S. 512 (1921); Arkadelphia Milling Co. v. St. Louis S.W. Ry., 249 U.S. 134 (1919). For a summary of these cases, see Middlewest Motor Freight Bureau v. United States, 433 F.2d 212 (1970). The early restitution cases required payment of refunds in rate cases to the party who had paid the increased charges under a federal court order staying a rate reduction.

75 In Interstate, the Supreme Court held that intermediate pipeline purchasers could claim entitlement to the court order refunds upon proof that they had passed the rate reduction on to their customers, but left open the possibility that intermediate pipeline purchasers who had not passed the rate reduction on to their customers could claim en- 
Several factors distinguish the court injunction case from an FPC proceeding under section 4(e). First, the injury suffered by consumers in Interstate was caused by the court's own order. If the Commission's reduction order had not been stayed, the Commission could have initiated section 5(a) proceedings to set new and lower rates for subsequent pipeline purchasers in the chain of distribution on the basis of lower supplier costs. State regulatory agencies could then have lowered the rates of local distributors for the same reason. On the other hand, neither the section 4(e) proceeding itself-a review of the supplier's rates-nor a delay in concluding that proceeding, caused injury to the ultimate consumer. Under the pre-1968 policy, if no tracking rate increase was filed by a pipeline purchaser, supplier increases never reached the consumer. If a tracking rate increase was filed and increased rates were passed on to the consumer, refunds were available to the extent those rates had been refunded by the supplier. Thus, if delay occurred in the section 4(e) refund proceeding, the available refund increased to match the increased consumer expenditures. Under pre-1968 section 4(e) proceedings, any actual injury to the consumer was caused by the Commission's failure to notice promptly an unreasonable return on investment made by the pipeline purchaser. On this ground alone, Interstate is inadequate support for the flow through refund policy.

A second and related distinction concerns the relative availability of protection to the consumer. Unless the court in Interstate impounded the excess money for the benefit of consumers, they would have been deprived of all opportunity to receive the benefits of a Commission rate reduction order until the stay was removed. On the other hand, at any time during a section 4(e) proceeding against a natural gas supplier, the Commission could have opened a section 5 (a) investigation of the rates currently charged by pipeline purchasers of the natural gas supplier. If the section 5 (a) proceeding had been completed prior to the section $4(\mathrm{e})$ hearing, the Commission could have authorized a pipeline purchaser to charge lower rates to its customers, guaranteeing the pipeline purchaser a fair and reasonable return after accounting for increased supplier costs. ${ }^{76}$ Unlike the situation in Interstate, a flow

titlement upon proof that their rates during the refund period were insufficient to generate a just and reasonable return. Id. at 582. The Commission resolved this question and held that an intermediate pipeline purchaser who fails to file a tracking rate increase is not entitled to a "risk-free second chance to demonstrate its need for greater revenues in the proceedings to dispose of its suppliers' refunds." Texas Eastern Transmission Corp., 39 F.P.C. 630, 642 (1968), aff'd, Texas Eastern Transmission Coxp. v. FPC, 414 F.2d 344 (5th Gir. 1969), cert. denied, 398 U.S. 928 (1970).

76 The Commission could attach to these new rates a condition that the pipeline pur- 
through refund order is thus not the only available method to protect the ultimate consumer in a section $4(\mathrm{e})$ proceeding.

\section{The Refund Gredit Option: How Shall Refund Obligations Be Satisfied?}

\section{A. Development of the Refund Credit Option}

Under section 4(e), "the Commission may, by order, require the natural-gas company ... to refund any amounts ordered by the Commission ...."77 On occasion, the Commission determines, in the exercise of its section 4(e) power, that partial refunds are appropriate. ${ }^{78}$ The courts have traditionally held that the Commission has broad discretion in making such determinations. ${ }^{70}$

chaser refund to its own customers all refunds received from natural gas suppliers covering the period after the conclusion of the section 5(a) investigation.

7715 U.S.C. $\$ 717 c$ (e) (1970) (emphasis added).

78 See, e.g., Hugoton-Anadarko Area Rate Case, 44 F.P.G. 761, 779-80 (1970) (employing partial forgiveness of refunds to avoid discrimination against one producer), affd, In re Hugoton-Anadarko Area Rate Case, 466 F.2d 974 (9th Cir. 1972); Hunt Oil \& Ref. Co., 32 F.P.C. 49, 50 (1964) (Commission uses cost-of-service study to excuse refund obligation of producer for periods in which costs exceeded revenues); Jack W. Grigsby, 32 F.P.C. 529, 530 (1964) (Commission extends the cost-of-service settlement program to small producers without requiring cost data and establishes general refund forgiveness figures).

79 Placid Oil Co. v. FPC, 483 F.2d 880, 907 (5th Cir. 1973) (discretion in section 4(e) case), aff'd sub nom. Mobil Oil Corp. v. FPC, 94 S. Ct. 2328 (1974); Public Serv. Comm'n v. FPC, 487 F.2d 1043, 1078 (D.C. Cir. 1973) (same), cert. granted and judgment vacated sub nom. Shell Oil Co. v. Public Serv. Comm'n, 94 S. Ct. 3166 (1974) (judgment vacated in light of Mobil Oil Corp. v. FPC, supra); In re Hugoton-Anadarko Area Rate Case, 466 F.2d 974, 990-91 (9th Cir. 1972) (same). See Mesa Petroleum Corp. v. FPG, 441 F.2d 182, 188-89 (5th Gir. 1971) (discretion in section 7 case); Continental Oil Co. v. FPC, 378 F.2d 510, 531 (5th Cir. 1967), cert. denied, Austral Oil Co. v. FPC, 391 U.S. 917 (1968) (same); Public Serv. Comm'n v. FPC, 329 F.2d 242, 249 (D.C. Cir. 1964) (same); Niagara Mohawk Power Corp. v. FPC, 379 F.2d 153, 158-59 (D.C. Gir. 1967) (discretion in licensing under Federal Power Act).

In its brief before the Supreme Court in Mobil Oil Corp. v. FPC, supra, petitioner Municipal Distributors Group (MDG) took the position that the Commission does not have discretion to waive refunds. Brief for Petitioner Municipal Distributors Group at 42-14, Reply Brief for Petitioner Municipal Distributors Group at 11-18, Mobil Oil Corp. v. FPC, supra. First, MDG argued that the word "may" should be given preemptory effect, citing Supervisors of Rock Island County v. United States ex rel. State Bank, 71 U.S. 446-47 (1867). "[W] terest or individual rights call for its exercise-the language used, though permissive in form, is in fact preemptory." This point is not determinative, however, since the Commission first decides whether refunds are in the public interest. Second, MDG offered an argument based on the grammatical construction of section $4(e)$ that certainly fails to settle the issue. Third, MDG notes that several of the cases relied on by the courts in section 4(e) cases are precedents under section 7 or the Federal Power Act. Finally, MDG argues that the exercise of discretion by the FPC would destory the requisite "bond of protection" provided by the Act. See text and note at note 1 supra. 
In several recent producer area rate proceedings, ${ }^{80}$ however, the Commission decided not only to excuse a portion of the producer refund obligation, but also to offer producers a refund credit option: the producer may "work off" its refund obligation by making monetary payments or by committing units of new gas to sales in interstate pipeline. ${ }^{81}$ The Commission hoped the option would ease the shortage of natural gas by providing additional incentives for the introduction of new gas into interstate pipeline. ${ }^{82}$

Under this novel procedure, which the Supreme Court has recently affirmed,83 a producer discharges a portion of its refund obligation for each unit of new gas dedicated to sales in interstate pipeline. Commitments to sell new gas to one pipeline purchaser in excess of the amount necessary to discharge the producer's existing refund obligation to that purchaser can be used to discharge proportionately the producer's refund obligations to other pipeline purchasers, ${ }^{84}$ but no more than 50 percent of the refunds owed to a particular pipeline purchaser may be reduced in this way. If a pipeline purchaser rejects a producer's offer to discharge its refund obligation through dedication of new gas to that purchaser, however, the 50 percent limit does not apply. ${ }^{85}$ The balance

80 See cases cited note 13 supra. The Commission first exerted jurisdiction over natural gas producers after the Supreme Court's decision in Phillips Petroleum Corp. v. Wisconsin, 347 U.S. 672 (1954), that independent producers are natural gas companies within the meaning of section 2(6) of the Natural Gas Act, I5 U.S.C. § 717a(6) (1970). See text and note at note 12 supra. After attempting to regulate producers on an individual level, the Commission decided to divide the country into a number of discrete geographical areas and to establish uniform rate schedules for producers within each area. See Statement of General Policy No. 61-1, 24 F.P.C. 818 (1960); Mobil Oil Corp. v. FPG, 94 S. Ct. 2328, 2343 (1974).

$81 \mathrm{New}$ gas in the Southern Louisiana area rate order included existing gas reserves committed to sales in interstate commerce in contracts dated on or after October 1, 1970, and discoveries of new gas reserves. Area Rate Proceeding (Southern Louisiana Area II), 46 F.P.C. 86, 147 (1971), aff'd sub nom. Placid Oil Co. v. FPC, 483 F.2d 880 (5th Cir. 1971), aff'd sub nom. Mobil Oil Corp. v. FPC, 94 S. Ct. 2328 (1974). This case will be used in this comment to illustrate the mechanics of the refund credit option.

82 Id. at 102; Area Rate Proceeding (Texas Gulf Coast Area), 45 F.P.G. 674, 689, 709-1I (1971), remanded sub nom. Public Serv. Comm'n v. FPC, 487 F.2d 1043 (D.C. Cir. 1973), cert. granted and judgment vacated sub nom. Shell Oil Co. v. Public Serv. Comm'n, 94 S. Ct. 3166 (1974) (judgment vacated and cases remanded for further consideration in light of Mobil Oil Corp. v. FPG, supra).

83 Mobil Oil Corp. v. FPG, 94 S. Ct. 2328 (1974), aff'g Placid Oil v. FPC, 483 F.2d 880 (5th Cir. 1973), aff'g Area Rate Proceeding (Southern Louisiana Area II), 46 F.P.C. 86 (1971).

84 See, e.g., Area Rate Proceeding (Southern Louisiana Area II), 46 F.P.C. 86, 148, aff'd sub nom. Placid Oil Co. v. FPC, 483 F.2d 880 (5th Cir. 1973), aff'd sub nom. Mobil Oil Corp. v. FPC, 94 S. Ct. 2328 (1974).

85 See, e.g., id. at 148: "[E]xcept that, if a buyer to whom a refund is owing rejects a bona fide offer of new dedications from the producer, the producer may, if it dedicates 
of a producer's refund obligations at the end of the refund credit program must be paid in cash. ${ }^{86}$

\section{B. Is the Refund Credit Option Within the Commission's Statutory Power?}

Under its section $4(e)$ authority to make a rate decision retroactive to the date the proposed rates became effective, the Commission undoubtedly may excuse part or all of a natural gas company's refund obligations. ${ }^{87}$ If the Commission decides, after balancing the interests of producers and consumers, that requiring full refunds would not be in the public interest, an order requiring partial refunds is appropriate. ${ }^{88}$

The refund credit option, on the other hand, is offered to the producer after the Commission has determined that an amount of funds is due and payable to the pipeline purchasers. ${ }^{89}$ At this point, the Commission is no longer "requir[ing] the natural gas company ... to refund ...." but is exercising administrative discretion to determine how and when the refund obligation is to be satisfied. The legislative history of the Natural Gas Act evidences no intention on the part of Congress to provide the FPG with such discretion. ${ }^{90}$ Moreover, the Supreme Court has expressed concern in Natural Gas Act cases over the illusory nature of refunds "in view of the trickling down process necessary to be followed, the incidental cost of which is often borne by the consumer, and in view of the transient nature of our society which often prevents refunds from reaching those to whom they are due."91 This concern led the Court to impose upon the Commission a duty to order payment of refunds at the earliest possible moment consistent with due process. ${ }^{.2}$

the offered reserves to sales to another interstate pipeline, credit against its obligation to the prospective buyer which first rejected the offer any unused credit over and above that which can be used to reduce the producer's refund obligation to the actual buyer."

86 See, e.g., id. at 147-48. Refund obligations in the Southern Louisiana Area that are not completely discharged by October 1,1977 must be paid in cash plus 7 percent interest. Id. at 148 .

87 See cases cited note 78 supra.

88 If a proposed rate has been in effect for a long period, for example, and significant changes have occurred in a company's costs or operations, the just and reasonable rate for future periods would be inapplicable to the refund period. United Fuel Gas Co., 12 F.P.C. 251 (1953).

89 For example, in the Southern Louisiana Area Rate Proceeding, the Commission first excused a portion of the refund obligation to determine the amount of refunds due to the pipeline purchasers. Area Rate Proceeding (Southern Louisiana Area II), 46 F.P.C. 86, 140-41 (1971), aff'd sub nom. Placid Oil Co. v. FPC, 483 F.2d 880 (1973), af'd sub nom. Mobil Oil Corp. v. FPC, 94 S. Ct. 2328 (1974).

20 See authorities cited notes 47-57 supra.

91 FPC v. Tennessee Gas Transmission Co., 371 U.S. 145, 154 (1962).

02 Id. at 155. 
The refund credit option falls short of meeting this responsibility; it substitutes a refund credit for a refund payment, allows a natural gas producer to discharge refund obligations to one pipeline purchaser through sales of natural gas to other pipeline purchasers, and permits a natural gas producer to take several years in which to work off its refund obligations. ${ }^{93}$

As noted above, the Supreme Court has interpreted section $4(\mathrm{e})$ to give the Commission two powers in addition to those normally exercised in a section 5 (a) proceeding: the power to suspend proposed rate changes and the power to make a final rate decision retroactive to the date the proposed rate change was put into effect by the natural gas company filing the change. ${ }^{94}$ It is difficult to maintain that the refund credit option can be fairly implied from either additional power..$^{95}$ The

93 In the Southern Louisiana Area Rate Proceeding, for example, the producers were given six years to "work off" their refund obligations through refund credits. Remaining refund obligations would be due in cash with interest at the end of the six-year period. Area Rate Proceeding (Southern Louisiana Area II), 46 F.P.C. 86, 148 (1971), aff'd sub nom. Placid Oil Co. v. FPC, 483 F.2d 880 (1973), aff'd sub nom. Mobil Oil Corp. v. FPG, 94 S. Ct. 2328 (1974).

94 See text and note at note 31 supra.

95 The Supreme Court has held, however, that the Commission has the discretion under section $4(\mathrm{e})$ to provide incentives for new gas in interstate pipelines by means of the "work off" provisions of the refund credit option. Mobil Oil Corp. v. FPC, 94 S. Ct. 2328 (1974), aff'g Placid Oil Co. v. FPC, 483 F.2d 880 (5th Cir. 1973). The Court fails to recognize that the decision to excuse a portion of a refund obligation and the decision to offer a refund credit option involve considerations of different discretionary issues.

In the Southern Louisiana Area Rate Proceeding, the Commission indicated that section 16 of the Act, which gives the Commission authority to issue such orders "as it may find necessary or appropriate to carry out the provisions" of the Act, might support its refund credit option. Area Rate Proceeding (Southern Louisiana Area II), 46 F.P.C. 86, 140 (1971), $a f f ' d s u b$ nom. Placid Oil Co. v. FPC, 483 F.2d 880 (1973), aff'd sub nom. Mobil Oil Corp. v. FPC, 94 S. Ct. 2328 (1974); Natural Gas Act § 16, I5 U.S.C. § 7170 (1970).

The Supreme Court has used section 16 to affirm the Commission's assertion of authority over certain aspects of the natural gas market when Congress has otherwise failed to provide specific authority. For example, in holding that section $1(\mathrm{~b})$ of the Act, giving the Commission jurisdiction over the transportation of gas in interstate commerce, included gas to be sold at both the wholesale and the retail levels, the Court noted that the Commission possessed broad powvers under section 16 to "devise effective means to meet these responsibilities." FPC v. Louisiana Power \& Light Co., 406 U.S. 621, 642 (1972); Natural Gas Act § 1, 15 U.S.G. § 717(b) (1970). Where Congressional grants of authority in the Act are more specific, however, there is less room for implicit grants of power through section 16. See, e.g., Murphy Oil Co. v. FPG, 431 F.2d 805 (8th Cir. 1970), holding that section 16 cannot enlarge specific authority granted the Commission by sections 4 and 5 of the Act. The Court of Appeals for the District of Columbia Circuit has recently noted that section 16 cannot enlarge the scope of permissible procedures beyond those that may be fairly implied from the nature and function of the substantive provisions of the Act. New England Power \& Light Co. v. FPC, 467 F.2d 425 (D.C. Cir. 1972). The refund credit option is not within the specific authority granted by section 4(e), and cannot be fairly implied from it. 
major purpose of the option-to produce incentives for the commitment of new gas to sales in interstate pipeline-is unrelated to the function of the refund provision-to guarantee just and reasonable rates for the period covered by the refund obligation. The refund credit option attempts instead to use monies collected under prior temporary rates to induce and finance the production of new gas. These goals are more appropriate to a Commission determination of the price for new gas, and constitute an explicit factor to be taken into account in establishing just and reasonable rates to be "thereafter observed and in force." 96

\section{Policy Considerations}

The refund credit option has important economic effects on the allocation of resources to the production of new gas, the possibilities for entry into the production of new gas, and the distribution of wealth among consumers. ${ }^{97}$ Even if institution of the option is within the Commission's statutory authority, it should be emphasized that the Commission can eliminate these economic effects and achieve its objectives merely by setting a higher price for new gas. ${ }^{98}$

1. The Allocation of Resources to the Production of New Gas. The refund credit option in effect provides those producers who have outstanding refund obligations a subsidy for the production of new gas.9 The failure to subsidize all producers equally, however, results in an inefficient allocation of resources to new gas production. Producers with subsidies in the form of refund credits will produce additional units of new gas that could have been produced at lower cost by other producers..$^{100}$ The degree of inefficiency is thus a function of the size of the refund credit.

90 Natural Gas Act § 5(a), 15 U.S.C. § 717d(a) (1970).

o7 See Public Serv. Comm'n v. FPC, 487 F.2d 1043, 1077-79 (D.C. Cir. 1973), cert. granted and judgment vacated sub nom. Shell Oil Co. v. Public Serv. Comm'n, 94 S. Ct. 8166 (1974). This comment will not address the potential free rider problem in the interrelationship between the refund credit option and the contingent escalation price incentive in producer area rate cases. See id. at $1077 \mathrm{n} .87$.

98 If the Commission is unable, due to political or other considerations, to set a higher price for new gas, the refund credit option may be a "second best" alternative. The refund credit is a disguised price increase. Of course, an inefficient allocation of resources would still result unless the refund credit option were available on an equal basis to all producers.

99 The refund credit option provides a larger subsidy for producers who initiated greater price increases and discriminates against producers who paid refund obligations in cash before the credit was made available.

100 Assume there are two producers of natural gas (A and B), only one (A) having outstanding refund obligations. If the price of a unit of new gas is $X$ cents, $B$ will have revenue of $X$ cents per unit of new gas produced and sold, but $A$ will have revenue of 
2. Possibilities of New Entry. The refund credit option may result in an inefficient allocation of resources to new gas production by subsidizing firms already in the market. Assume, for example, that two firms ( $A$ and $B$ ) compete for a lease on a natural gas reserve, and $B$ is a new entrant with no outstanding refund obligations. If $A$ and $B$ have the same cost structures, A will be able to outbid B since it gets a subsidy for gas produced from the reserve. If $B$ has a lower cost structure than $A$ (due to a technological advantage), A might still outbid $B$ for the lease if the amount of A's expected subsidy exceeds the amount of B's cost saving. The refund credit option thus creates the possibility that efficient new competitors will be locked out of the market, and this possibility is a function of the size of the refund credit. This inefficiency can be eliminated by giving the same subsidy to a new entrant. Once again, the simplest way to accomplish this is through a higher uniform new gas price without a refund credit option.

3. Wealth Distribution Among Consumers. Under the terms of the refund credit option, the new gas produced can be sold to consumers other than those to whom producers have outstanding refund obliga-

$(X+Y)$ cents, where $Y$ is the amount of the per unit refund credit. In other words, $A$ receives both $\mathrm{X}$ cents per unit of gas sold and a $\mathrm{Y}$ cent reduction in his outstanding refund obligations. In the Southern Louisiana Area Rate Proceeding, for example, where the refund credit was one cent per unit of new gas, producers with refund obligations received in effect an additional cent for each unit of new gas sold in interstate pipeline.

Both $A$ and $B$ will increase the production of natural gas to the point where the marginal cost of an additional unit of new gas is equal to the marginal revenue received for that unit of gas when sold. If A and $B$ face the same rising cost structure, $A$ will produce more gas than B because the greater marginal revenue per unit of gas sold can be used to offset the rising marginal cost to $A$ of additional units of gas. From an economic viewpoint, this result is inefficient since the total cost of producing the same amount of gas could be reduced by shifting production from $A$ to $B$. Because $A$ produces at a level at which A's marginal cost is greater than B's marginal cost, there is a net saving if A produces one unit less, and $B$ produces one unit more.

The optimal solution from an economic viewpoint is to have $A$ and $B$ produce at the point at which the marginal cost to $A$ is equal to the marginal cost to $B$. This may be achieved simply by establishing one uniform new gas price for both $A$ and $B$ without a refund credit option. In setting the uniform new gas price, the Commission can consider the necessity for an increased supply of new gas to avoid a shortage of natural gas.

Of course, since there is a net saving to be derived from a shift of production from $A$ to $B$, there is an incentive for $A$ and $B$ to merge and lower the total cost of production. If the costs of merger exceed the net saving, a merger will not take place. Even if a merger does take place correcting the inefficiency, there is still an unnecessary waste of resources in the form of the costs of merger.

There is also an incentive for two firms to merge if one firm will be unable to work off its refund obligations in the time period set under the refund order. Such a firm would seek to merge with a firm that either has no refund obligations or that will be able to produce far more new gas than is necessary to work off its refund obligations. The determinants of a possible merger are the costs of merger and the benefits to be derived. 
tions. This results in a wealth transfer from consumers with refund claims to other consumers, since the refund credit option enables the Commission to set the price of new gas below what it otherwise would have been. Changes in the distribution of wealth are not within the Commission's statutory purpose. These wealth transfer effects can be eliminated either by requiring proportional delivery of the new gas to those consumers who can enforce refund obligations, or by substituting a higher new gas price without a refund credit option.

\section{ConcLusion}

This comment has examined the development of two new Federal Power Commission refund procedures governing the distribution of section 4(e) refunds. It concludes that the flow through approach to the determination of a refund beneficiary is not within the Commission's statutory power because it violates the Congressional ban on reparations and expands the narrow scope of review that the Supreme Court has permitted in section 4(e) refund proceedings. Furthermore, the distribution of refunds by federal courts in proceedings to enjoin a Commission rate reduction order provides no support for a similar approach in agency refund proceedings under section 4(e).

Although several federal courts have found statutory support for the refund credit option, it is submitted that this option is beyond the discretion that can be exercised in section $4(\mathrm{e})$ proceedings. Even if the refund credit option is a valid technique under section $4(e)$, however, there is little justification for a program which misallocates resources and redistributes wealth when a simpler administrative alternative is available. ${ }^{101}$

Eugene J. Comey

101 The Supreme Court has concluded, however, that the Commission's "assescment of the need for the refund credits, compared to the costs and benefits of some other scheme" passed the substantial evidence test. See Mobil Oil Corp. v. FPC, 94 S. Ct. 2328, 2853 (1974). 